\title{
PERAN DAN PENGARUH FILSAFAT DAN LOGIKA DALAM METODE ISTINBĀT HUKUM ISLAM
}

\author{
Abbas Arfan \\ Fakultas Syariah UIN Maliki Malang \\ Email: abunawalrajwa@gmail.com
}

\begin{abstract}
Muslim scholars argue that the relationship between usul fiqh, philosophy, and logic is 'alaqah ibtiyajizyah manhäjiyyah (methodological need relationship) because the legal ground in the theory of usul figh is not only derived from the scripture (naqli) such as the Qur'an and Hadits but also from logic ('aqli). In order to have more understanding in the textual reason (naqli), it requires logical reason or logical competence. This paper attempts to analyze critically and comprehensively such relationship so it will be revealed the position of philosophy and logic in Islamic law. This is important since Muslims still view that philosophy and logic are irrelevant with Islam. This study demonstrates that the relationship between philosophy and logic with Islamic law is very strong because the methodology of Islamic law (usul fiqh) accommodate them. So it is a methodological relationship. Thus, claiming that these two disciplines are forbidden in Islam, as Muslims may assume, is untenable. In contrast, they are an important element in the Islamic legal system.
\end{abstract}

Keyword: relationship, ușül fiqh, philosophy, logic, istinbăt -Islamic Law.

DOI: http://dx.doi.org/10.20414/ujis.v19i1.1252

\section{Pendahuluan}

DOMAIN filsafat dalam wilayah pemikiran Islam merupakan bagian yang sangat Urgen. Urgensi dan peran filsafat dapat dicermati dan perkembangan peradaban manusia yang tetap dinamis. Kedinamisan tersebut mengajak para pemikir muslim untuk melakukan interpretasi, bahkan interpretasi ulang terhadap teks (al-Qur'an-Sunnah) yang masih bersifat umum agar tidak 
kering dan nilai-nilai universal ajaran Islam, karena filsafat tidak hanya mengacu pada bagian tertentu dan realitas, melainkan secara totalitas. Dalam melihat keseluruhan realitas, filsafat senantiasa berupaya mencari asas yang paling hakiki (ontologis) dan keseluruhan realitas. Mencari asas awal berarti juga berupaya menemukan sesuatu yang esensi dan realitas. Di samping itu, filsafat membebaskan manusia dari cara berfikir yang mistis dengan membimbing untuk berfikir secara rasional. Ia juga membebaskan manusia dan cara berfikir yang picik, sempit, rigid dan dangkal, dengan membimbing untuk berfikir secara luas dan mendalam, sistematis, bahkan radikal dalam upaya menemukan esensi suatu permasalahan. Dengan kata lain, filsafat membimbing manusia untuk berfikir secara sistematis, logis, integral dan menyeluruh. ${ }^{1}$

Sedangkan berfikir secara sistematis, logis, integral dan menyeluruh disebut juga dengan istilah metode, karena arti metode sebagaimana tersebut dalam Kamus Besar Bahasa Indonesia (KBBI) adalah: "cara teratur yang digunakan untuk melaksanakan suatu pekerjaan agar tercapai sesuai dengan yang dikehendaki; cara kerja yg bersistem untuk memudahkan pelaksanaan suatu kegiatan guna mencapai tujuan yg ditentukan." Adapun ilmu yang mempelajari bagaimana menggali metode-metode dan mengaplikasikannya dalam istinbāt (mengeluarkan hukum secara deduktif) hukum Islam adalah ilmu ushul fiqh.

Sebagian ulama menyatakan bahwa hubungan antara ushul figh dengan filsafat dan logika adalah aläqah ibtiyäjiyyah manhäjiyyah (hubungan kebutuhan metodologis), karena dalil-dalil dalam ushul al-fiqh tidak hanya berupa dalil 'aqli (al-Qur'an dan al-Sunnah), tapi juga dalil 'aqli (akal sehat). Disamping itu, memahami dalil-dalil 'aqli-pun memerlukan bantuan akal untuk berfikir dan menyimpulkan, sedangkan ilmu mantik (logika) dan filsafat adalah ilmu yang berfungsi untuk membimbing dan mengoptimalkan cara berpikir dan mengambil kesimpulan agar terhindar dari kesalahan, maka kedua ilmu ini berfungsi sebagai metode berfikir bagi ushul fiqh. Makalah ini berusaha

${ }^{1}$ Jan Hendrik Raper, Pengantar Filsafat (Yoyakarta: Kanisius, 1996), 27. 
menganalisis hubungan tersebut secara käffah; jelas, utuh dan menyeluruh, agar didapat pemahaman yang käfah juga terhadap kedudukan filasafat dan logika dalam Islam. Agar tidak lagi terjadi diskriminasi terhadap ilmu filsafat dan logika yang oleh sebagian orang Islam diangap sebagai ilmu yang haram untuk dipelajari, terlebih memanfaatkan keduanya. ${ }^{2}$

\section{Metodologi Istinbāt dalam Hukum Islam}

Secara umum metode yang dikembangkan ulama untuk menggali (istinbät) hukum Islam seperti yang dikaji dalam ushul fiqh klasik dapat dibedakan menjadi dua bagian besar, yaitu metode literal (tariqah lafíiyyah) dan metode argumentasi atau ekstensifikasi (tariqah ma'nawiyyah). Metode literal ditujukan terhadap teks-teks syariah yang berupa al-Qur'an dan Hadis untuk mengetahui bagaiman cara lafaz-lafaz kedua sumber itu menunjukan kepada hukum-hukum yang dimaksudnya. Oleh karena itu, dasar metode ini adalah analisis lafaz-lafaz al-Qur'an dan Hadis dengan bertitik tolak pada kaidah bahasa Arab. Dalam metode ini dijelaskan bagaimana cara suatu lafaz syariah menunjukan makna yang dikehendakinya, bagaimana cara menyimpulkan makna itu dari kata-kata tersebut dan bagaimana mengkompromikan berbagai makna yang secara se pintas

2Memang diakui terdapat perbedaan pendapat di kalangan ulama tentang hukum mempelajari ilmu filsafat (juga logika, karena ia adalah bagian dari filsafat). Sebagian ulama mengharamkannya secara mutlak, sehingga filsafat harus ditolak karena sebagai bid'ah, kafir, zindiq, mulhid, haram dan Majusi. al-Gazālī dalam al-Tahäfut-nya menghitamkan (mengharamkan) ajaran filsafat secara sistematis dan menyudahi kegiatan filsafat di wilayah timur Islam. Ibn al-Ṣalāh al-Kurdī (w. $643 \mathrm{H} / 1245 \mathrm{M}$ ) dengan tega mengatakan bahwa "filsafat merupakan pokok kebodohan dan penyelewengan, bahkan kebingungan dan kesesatan. Barangsiapa yang berfilsafat, maka butalah hatinya dari kebajikan syariat suci. Siapa mempelajarinya, maka diiringi kehinaan, tertutup bagi kebenaran dan tergoda oleh setan. Para ulama menyelami lautan kebenaran dan bahasan tanpa ilmu mantik atau filsafat. Barangsiapa berpendapat bahwa kedua ilmu itu (filsafat dan logika) berfaidah, maka dia telah dibujuk dan ditipu oleh setan. Para penguasa wajib memecat mereka dari lembaga pengajaran dan memenjarakannya". Bahkan al-Suyūṭ̄ mengklaim bahwa ulama telah ijma' (sepakat) terhadap keharaman filsafat, sebagaimana dinukil Alawī Ibn Aḥmad al-Saqqāf dalam bukunya al-Fawäid al-Makkiyyah. 
tampak saling bertentangan. Penulis kitab ushul fiqh seperti 'Abd. Wahāb Khallāf, Muḥammad Abū Zahrah, A ̣̣mad Ibrāhim Bik, Abd. Hamid Hakim (Minangkabau) dan lain-lain, adalah diantara beberapa ulama muta'akhirin yang menggunakan metode literal ini dalam kajian ilmu ushul figh dengan memakai metode pendekatan dan gabungan antara metode (mazhab) alMutakallimün dan al-Hanafiyyah, terbukti dengan memasukan metode istihsān yang jelas-jelas di tentang oleh Imam Shäfi'i sebagai seorang penggagas metode al-Mutakallimūn ${ }^{3}$, juga dengan memasukan beberapa metodologi kontradiktif, seperti al'urf, mașälih mursalah, dan lain-lain. ${ }^{4}$

Metode ekstensifikasi (argumentasi) yang esensinya adalah usaha dan upaya untuk memperoleh suatu hukum Islam dengan cara pemekaran dan perluasan makna suatu teks syariah yang bersifat eksplisit. Hal ini dilakukan dengan cara menggali causalegis (illat) suatu nash untuk diterapkan pada kasus-kasus yang serupa yang tidak secara eksplisit termasuk di dalamnya. ${ }^{5}$ Metode ini oleh kalangan Ahl Sunnah dikenal dengan qiyās. Atau juga dengan jalan menggali semangat, tujuan dan prinsip umum, yang terkandung dalam suatu nas untuk diterapkan secara lebih luas pada masalah lain yang diharapkan mewujudkan kemaslahatan yang sama, ${ }^{6}$ yang pernah digagas oleh al-Shāṭibi dalam kitab "al-Muwāfaqāt" dengan istilah konsep maqāsid alshari'ah.

Kedua metode di atas jika diurai akan menjadi tiga pendekatan analisis yang telah dikembangkan oleh para ulama ushul fiqh dalam melakukan kajian hukum, yaitu:

${ }^{3}$ Mustafā Sa ìd al-Khann (w. 2008 M) dalam bukunya al-Käfì al-Wäfí fi Ușül al-Fiqh al-Islämì membuat terobosan baru mengenai kecenderungan aliran dalam ilmu ushul fiqh. Bila sebelumnya hanya dikenal dua aliran saja, yaitu al-Mutakallimün dan al-Fuqahä atau al-Shäfíyyah dan al-Hanafoyyah, alKhann membaginya menjadi lima bagian: al-Mutakalliminn, al-Hanafizyah, alJàm'i (gabungan antara keduanya), Takbrï al-Furù' 'alā al-Usūl dan alShätibiyyah (al-Maqāsidizyah).

${ }^{4}$ Abbas Arfan, Geneologi Pluralitas Maŗab dalam Hukum Islam (Malang: UIN Malang Press, 2008), 68-9.

${ }^{5}$ Amir Mu'allim and Yusdani, Konfigurasi Pemikiran Hukum Islam, trans. Konfigurasi Pemikiran (Yogyakarta: UII Press, 2001), 93.

'Ibid., 94. 
pendekatan melalui kaidah-kaidah kebahasaan (qawāid al-lughah), yakni kaidah-kaidah yang disusun untuk memahami makna lafaz dalam konteks makna hukumnya; (2) pendekatan melalui analisis 'illat al-bukm (manhaj ta'lili), yakni kaidah-kaidah untuk mengkaji posisi hukum dari berbagai kejadian yang tidak dinyatakan secara eksplisit dalam teks al-Qur'an dan al-Sunnah, dengan melihat 'illat hukum; dan (3) pendekatan melalui analisis maslahat (manhaj istiṣlāhi), yakni kaidah-kaidah untuk mengkaji posisi hukum dari berbagai kejadian dengan mempertimbangkan kemaslahatan bagi kehidupan manusia yang akan ditimbulkan oleh rumusan pemikiran hukumnya itu. ${ }^{7}$

\section{Pengaruh Filsafat-Logika dalam Pendekatan Kebahasaan}

Pendekatan pertama melalui kaidah-kaidah kebahasaan (qawāid al-lughah) ini sangat dipengaruhi ilmu filsafat terutama ilmu logika yang dipadukan dengan ilmu kaidah bahasa Arab (karena yang dikaji adalah teks-teks al-Qur'an dan al-Sunnah yang berbahasa Arab), terutama aliran (mazhab) al-Hanafiyyah yang memiliki kajian analisis ke-dalälat-an lafaz, yakni analisis dari segi cara pengungkapan lafaz dalam kaitannya dengan makna yang dikandung oleh lafaz tersebut. Dalam konteks ini, ulama Hanafiyyah mengklasifikasikannya kepada empat metode, yaitu: ${ }^{8}$

1) Thärat al-nașs; yakni sistem analisis untuk menemukan pesan hukum dari lafaz dengan melihat pada makna lafaz, sama ada makna eksplisitnya maupun makna yang lahir dari cara pengungkapannya serta makna interpretasi yang dapat dipahami dari perkataan tersebut. Dengan demikian, sistem analisis 'ibärat al-nașs adalah memahami pesan hukum dari ungkapan lafaz, baik makna semantiknya secara langsung, maupun makna hukum yang dapat dipahami melalui analisis interpretasi terhadap lafaz tersebut.

2) Isyārat al-naș:; yaitu sistem analisis makna hukum yang ditunjukan lafaz bukan melihat pada ungkapannya, dan

${ }^{7}$ Muhammad Hasbi Umar, Nalar Figh Kontemporer (Jakarta: GP Press, 2007), 254.

8Wahbah al-Zuhaylī, Usūl al-Figh al-Islämī, vol. 1 (Damascus-Suriah: Dār al-Fikr, 1996), 202-3. 
bukan pula oleh alur kalimatnya, tetapi pada logika yang ditimbulkannya. Sehubungan dengan posisinya yang tersembunyi, maka pesan hukum tersebut harus dikaji oleh mujtahid, melalui analisis mendalam dengan memperhatikan muatan-muatan normatif dari logika ungkapan lafaz secara keseluruhan.

3) Dalālat al-nașs; yakni petunjuk lafaz hukum tidak hanya mengacu kepada sesuatu yang diungkapkan, tetapi juga menjangkau perbuatan di luar ungkapan lafaz, karena terdapat kesamaan "illat. Dengan melihat kepada kesamaan 'illat tersebut, jumhur uiama, selain Abu Hanifah, menyebut sistem analisis ini dengan istilah "mafhüm muwäfaqab", yang mereka bagi kepada dua kategori, yaitu: pertama, fahwā alkhitäb, jika perbuatan di luar ungkapan nas itu lebih kuat iilat-nya dari objek yang diungkapkan nas; dan kedua, labn al-khitāb, jika kekuatan 'iilat-nya sama. Pendekatan analisis dengan menggunakan metode dalälat al-nașs atau mafhüm muwäfaqah ini adalah termasuk metode analogis logika, yakni menganalogikan kejadian di luar ungkapan nas, pada objek yang diungkapkan oleh nas, dengan melihat pada kesamaan 'iilat antara kedua kejadian atau perbuatan tersebut. Jika keduanya memiliki kesamaan "illat, maka keduanya juga patut memiliki kesamaan hukum.

4) Dalälat al-iqtidā'; yakni sistem analisis makna hukum dari lafaz dengan mengkaji penggalan kata yang tersembunyi dalam komposisi kalimatnya, namun ditunjukan oleh susunan kalimat itu sendiri, sehingga kalimat tersebut menjadi lebih dapat dipahami pesan hukumnya secara benar, jika penggalan kata itu telah ditemukan, melalui analisis tersebut. Metode analisis dalam pendekatan dalälat al-iqtidā ini adalah logika semantik, yakni melihat kemestian susunan kalimat yang tersusun sempurna secara gramatika, namun belum sempurna dalam merefleksikan makna. Tugas mujtahid dalam konteks ini adalah memastikan penggalan kata yang tersembunyi dalam komposisi kalimatnya itu, dengan melihat pada keharusan komposisi kalimat sesuai dengan pesan hukum dari kalimat tersebut. 


\section{Pengaruh Filsafat-Logika dalam Pendekatan Analisis Tllat Hukum}

Begitu juga pendekatan kedua; pendekatan melalui analisis 'illat hukum ('illat al-bukm) -yang dikenal dengan istilah manhaj ta'lili- tidak luput dari pengaruh ilmu filsafat dan logika. Manhaj ta'lili adalah analisis hukum dengan melihat kesamaan 'illat atau nilai-nilai substansial dari persoalan aktual tersebut dengan kejadian yang telah diungkapkan oleh nas. Metodologi yang telah dikembangkan oleh para ulama dalam corak analisis ini tersebut adalah qiyās dan istibsān. Akan tetapi yang paling kuat pengaruh ilmu filsafat dan logika adalah metode istinbät hukum yang disebut qiyās.

Qiyass merupakan metode ijtihad yang mendapatkan prioritas utama yang digunakan oleh mujtahid, karena qiyäs merupakan metode ijtihad yang amat jelas dan akurat. Hampir semua kitab ushul fiqh membahas dalil qiyās dan persoalan "illat-nya. Secara etimologi, kata qiyās berarti ukuran dan persaman, ${ }^{9}$ yakni mengetahui ukuran sesuatu dengan menghubungkannya pada yang lain dan menyatakan sesuatu dengan sesuatu yang lain. Sedangkan dilihat dari segi terminologi, yang biasa digunakan oleh para ulama usūl adalah "menghubungkan sesuatu yang belum dinyatakan ketentuan hukumnya oleh nas kepada sesuatu yang sudah dinyatakan ketentuan hukumnya oleh nas karena keduanya memiliki kesamaan illat hukum". Menurut "Abd Al-Hākim 'Abd al-Rahmān, qiyās adalah "membawa sesuatu yang belum diketahui kedudukan hukumnya pada sesuatu yang sudah diketahui hukumnya rnelalui nas, dalam rangka menetapkan atau menafikan hukum untuk kejadian tersebut, karena ada yang mempersatukan antara keduanya berupa sifat-sifat yang dimiliki oleh keduanya". ${ }^{10}$

Penggunaan kata 'membawa' (baml) dalam definisi di atas dimaksudkan untuk lebih mempertegas sifat qiyās yang menetapkan suatu hukum untuk sesuatu kejadian atau keadaan, dengan ketetapan hukum kejadian atau keadaan lain yang telah

'Sha'bān Muhammad Ismāî̀1, Dirāsāt Hawl al-Ijmā' wa al-Qiyās (CairoMesir: Maktabah al-Nahdah al-Mișriyyah, t.th.), 153.

10Umar, Nalar Fiqh, 72-3. 
dinyatakan ketetapan hukumnya oleh nas. Inilah hakikat qiyas, yang prosedur kajiannya senantiasa melibatkan nas dalam menetapkan hukum untuk berbagai kejadian aktual, sejauh memiliki kesamaan "illat antara kejadian tersebut dengan objek kejadian atau perbuatan yang dikemukakan langsung oleh nas. ${ }^{11}$

Pengetian qiyās semacam ini adalah qiyās dalam pemahaman Shāfi'ì dan setelahnya, sedangkan qiyās sebelum Shāfi'i hanya digunakan untuk menunjukan kesamaan dua kasus yang serupa yang dimulai dengan penggunaan pendapat rasio pribadi (ra'y) dalam kasus-kasus yang tidak ada nasnya. Pengertian qiyās setelah Shāfi'ì memuat empat unsur yang menjadi bangunannya, yaitu: (1) al-far' (kasus baru atau cabang), (2) al-aș (kasus asli yang ada dalam nas), (3) al-illat (ratio legis), yaitu alasan serupa antara al-așl dan far' yang berupa sifat umum yang terdapat pada keduanya, dan (4) al-bukm, yaitu hukum yang dipergunakan qiyās untuk memperluas hukum dari asal ke far' atau norma hukum yang dinisbatkan kepada kasus baru yang ditransfer dari kasus lama ke kasus baru karena kesamaan antara kedua kasus. ${ }^{12}$

Penemuan "illat hukum (masälik al-illah) dalam sebuah kasus yang terdapat dalam teks secara garis besar dapat dilakukan dengan dua metode, yaitu: (1) sah (valid), yakni metode-metode yang keabsahannya diakui oleh para fuqaha $\bar{a}$, dan 2) dugaan (probable) atau żaniyyah atau mutawabhamah, yang keabsahannya masih bersifat dugaan dan kemungkinan. Metode yang pertama terbagi menjadi dua yaitu ijm $\bar{a}^{-}$(consensus) dan nas (the text). Sedangkan nas terbagi menjadi dua lagi, yaitu nas yang eksplisit (sarīh) dan implisit (imā wa tanbīb). ${ }^{13}$ Sementara itu, metode yang kedua yang bersifat dugaan ada lima, yaitu: munāsabah (kesesuaian), shabh (keserupan), țard atau țarādi (kebersamaan atau kebetulan), dawrān (perputaran), juga disebut

${ }^{11}$ Ibid.

12Abū Zahrah, Usūl al-Fiqh (Mesir: Dār al-Fikr al-'Arabī, 1990), 351.

${ }_{13}^{3}$ Sementara sebagian ulama ada yang membagi masälik al-íllab menjadi tiga bagian besar, yaitu: 1) al-Nas, 2) al-Ijmā' dan 3) al-Munäsabab atau lebh jelas lagi dengan al-Sabr wa al-Taqsim. Ada juga yang langsung membaginya secara rinci menjadi 9 (sembilan), yaitu: 1) al-Nas, 2) al-Ijmāt, 3) al-Imä', 4) alSabr wa al-Taqsim, 5) al-Munäsabah, 6)al-Shabh, 7) al-Ṭard, 8) al-Dawrän, dan 9) Tanqīh al-Manät. al-Zuhayli, Ușül al-Fiqh, 661-95. 
tard wa 'aks (kebersamaan dan kespesifikan) dan sabr wa taqsim (penyelidikan dan klasifikasi). ${ }^{14}$

Selain metode tersebut, masih ada perdebatan di kalangan ulama tentang jumlah dan jenis lainnya. Misalnya, sebagian fuqabà menganggap metode tanqīh al-manàt (pembersihan dan dasar ketetapan hukum), tahqiq al-manät (verifikasi atau realisasi dasar ketetapan hukum) dan takhrij al-manät (pengambilan dasar ketetepan hukum) dapat digunakan sebagai metode penetapan 'illat. Namun ketiga metode ini ditolak oleh al-Gazālī dan alAmidī sebagai masāilik al-ïllah, tetapi keduanya memasukannya dalam ijtihäd fi al-'illah (ijtihad dalam mencari 'illat).

Metode tard wa 'aks (kebersamaan dan kespesifikan) sering digunakan al-Amidī dan Ibn al-Hājib yang dalam istilah ushul fiqh lebih dikenal dengan istilah dawrän (rotation), yaitu apabila ada kualitas hukum tertentu, maka hukum juga ada bersamaan dengannya (kualitas hukum), dan jika kualiatas hukum tersebut tidak ada, maka hukum pun tidak ada. Misalnya, diperbolehkan meminum jus anggur selama tidak memabukkan dan tidak diperbolehkan jika memabukkan, dan juga dibolehkan jika ia berubah menjadi cuka. Selanjutnya, metode as-sabr wa al-taqsim (penyelidikan dan klasifikasi, yaitu metode klasifikasi dan eliminasi secara berturut-turut. Metode ini menyortir semua alasan yang dianggap kandidat dan dengan proses eliminasi berturut-turut, akan sampai pada sebuah alasan yang tetap. Misalnya, roti tidak menjadi objek

${ }^{14}$ Metode al-sabr wa al-taqsim artinya mengukur atau menguji beberapa sifat yang terdapat dalam suatu hukum dan kemudian memilih semua kemungkinan yang dianggap 'illat hukum setelah menghimpun sifat-sifat yang patut dijadikan 'illat. Metode munāsabah artinya mencari kesusaian antara sifat atau sebab hukum dengan kasus hukum dalam rangka menciptakan kebaikan dan menolak kerusakan. Metode tard artinya mencari sifat yang sesuai dengan ketetapan hukum atau ketatapan hukum ada bersamaan dengan sifat atau 'illat dalam semua kasus, kecuali dalam hal-hal yang diprdebatkan. Metode shabh yaitu menyamakan sesuatu kepada yang lain karena keserupaan bentuknya, merupakan qiyās berdasarkan keserupaan dalam makna, merupakan kualitas yang menyerupai 'illat. Metode dawrān maksudnya tetapnya hukum karena adanya sifat tertentu dan tidak adanya sifat tersebut menetapkan pula tidak adanya hukum. Ismāî̀, Dirāsāt Hawl, 225-46. 225-246. 
transaksi yang berbau riba. Menurut mazhab Shāfi'̄ ada tiga alasan larangan yang mungkin, yaitu: dapat ditakar dengan timbangan, dapat ditakar dengan isi dan dapat dimakan. Akan tetapi, roti dikatakan tidak dapat dijual dengan timbangan dan tidak dapat dijual dengan isi sehingga yang tersisa adalah alasan dapat dimakan. ${ }^{15}$

Kalau begitu, metode as-sabr wa al-taqsim ini dalam logika disebut juga dengan proposisi bersyarat yang terpisah (al-shart almunfasil), sejenis silogisme yang digunakan untuk menemukan sebab-sebab rasional (illah aqliyyah) dalam persoalan rasional (ma'qulät), karena al-qadiyyah al-shartiyyah al-munfasilah (proposisi kondisional disjunktif) adalah proposisi yang berisi pernyataan alternatif yang menghubungkan kedua bagian dengan kata penghubung opsi seperti "atau". ${ }^{16}$ Artinya, dari dua proposisi yang saling terkait satu dan yang lain sebagai dua alternatif atau pemisah yang saling meniadakan satu sama lainnya.

Berdasarkan cara-cara penemuan "illat hukum dalam qiyās di atas, maka kita dapat menganalisa lebih jauh lagi. Sistem berfikir "illat sangat erat kaitannya dengan sistem logika Aristoteles maupun Stoic. Sistem penemuan ' illat dengan shabh sangat terpengaruh oleh model silogisme Aristoteles (yang kadang disebut dengan istilah qiyās 'aqli atau qiyās mantiqui). Misalnya, Shāfi'i menegaskan bahwa mengusap tangan dengan debu dalam tayammum adalah sampai sikut berdasarkan analogi membasuh tangan dalam berwudu, walaupun ayat tayammum (al-Maidah: 6) tidak menyebut sampai siku. ${ }^{17}$ Apabila

15Wael B. Hallaq, Sejarah Teori Hukum Islam (Jakarta: Rajawali Pres, 2000), 133-6.

16Zainun Kamal, Ibn Taimiyah Versus Para Filosof: Polemik Logika (Jakarta: Rajawali Pers, 2006), 28.

${ }_{17 " \mathrm{Hai}}$ orang-orang yang beriman, apabila kamu hendak mengerjakan shalat, Maka basuhlah mukamu dan tanganmu sampai dengan siku, dan sapulah kepalamu dan (basuh) kakimu sampai dengan kedua mata kaki, dan jika kamu junub Maka mandilah, dan jika kamu sakit atau dalam perjalanan atau kembali dari tempat buang air (kakus) atau menyentuh perempuan, lalu kamu tidak memperoleh air, Maka bertayammumlah dengan tanah yang baik (bersih); sapulah mukamu dan tanganmu dengan tanah itu. Allah tidak hendak menyulitkan kamu, tetapi Dia hendak membersihkan kamu dan menyempurnakan nikmat-Nya bagimu, supaya kamu bersyukur." 
demikian, dapat disusun silogisme dengan gambaran sebagai berikut:

Premis mayor : Membasuh tangan dengan air dalam wudu sampai siku

Premis minor : Tayammum adalah pengganti wudu dalam kondisi tertentu

Middle term : Thaharah (bersuci)

Kesimpulan : Mengusap tangan dengan debu dalam tayammum harus juga sampai siku

Sebagai kesimpulan, Shāfi'ī membuktikan berdasarkan qiyās shabh bahwa mengusap tangan dalam tayammum adalah sampai siku. Struktur qiyās tersebut menunjukan bahwa ia memiliki kesamaan dengan silogisme Aistoteles, sekalipun tidak dapat dibuktikan secara pasti bahwa para fuqaha meminjam dari sana. Sesuatu yang permanen dalam logika qiyās adalah komposisi yang sama dengan fungsi yang sama pula seperti terdapat dalam komposisi Aristoteles, sedangkan yang berubah adalah kebutuhan akan premis mayor yang bersumber dari sesuatu yang lebih "suci" dalam pengertian sumber.

Tidak hanya itu, logika ushul fiqh terutama qiyās tidak hanya mengakses pada logika Aristoteles, lebih jauh lagi ia lebih banyak bersinggungan dengan logika Stoik. ${ }^{18} \mathrm{Hal}$ ini dapat dibuktikan dengan penggunaan conditional sentence "jika...maka..." yang terdapat dalam, terutama, penemuan 'illat dengan metode tard wa 'aks atau dawrān, seperti kaidah "illat yang terkenal: "jika ada kualitas hukum maka ada hukum dan jika tidak ada kualitas hukum maka tidak ada hukum." (الحكم يدور مع علثه, وجودا و عدما).

18Logika Stoic atau juga sering disebut sebagai logika mazhab Stoa adalah logika model silogisme hipotesis dan disjungtif. Yang disebutkan pertama, bergumul dengan penalaran-penalaran abstrak yang bersifat mungkin, jika, memakai pernyataan "jika-maka", atau kombinasi pernyataan "jika-maka” dan pernyataan katagoris. Sedangkan yang disebutkan terakhir, yang dalam uraian kuno tentang silogisme, pembedaan dibuat diantara arti lemah "entah-atau" (sering disebut alternative) dan arti kuat (sering disebut disjungtif). Kedua logika ini telah terkonsep dalam logika Stoik. Berbeda dengan logika Aristoteles yang menggunakan silogisme katagorik yaitu silogisme yang semua proposisinya katagorik (al-Qadiyyah alHamliyyah). 
Hal ini juga diperkuat dengan penelitian Josef van Ess, ${ }^{19}$ ia mengatakan: "jika diproyeksikan ke dalam ide Stoik, maka model dawrān ini tidak lebih dari kreteria validitas klausa bersyarat dan mungkin sebanding dengan logika materil pada masa Hellenistik."20 Sementara itu, silogisme disjungtif ditemukan dalam logika Stoik seperti juga silogisme hipotesis. Dengan demikian, logika qiyās telah mengalami pembauran antara logika Aristoteles dan logika Stoik, namun dari penjelasan tentang penemuan 'illat hukum, logika Stoik lebih mendominasi dari logika Aristoteles.

Bahkan dalam sebuah penelitian terungkap data bahwa dari 9 (sembilan) masälik al-íllah di atas itu beberapa di antaranya mirip dengan 5 (lima) metode yang ada ilmu logika pada bagian penyimpulan kausal. Karena dalam ilmu logika ada pembahasan yang disebut "penalaran tidak langsung proposisi kategoris" yang dalam kitab mantik di sebut dengan "al-istintäj/al-istidläl ghayr alMubāshir" yang juga sering di singkat dengan sebutan al-qiyās. Kajian qiyās dalam ilmu logika di bagi 3 (tiga), yaitu: (1) induksi

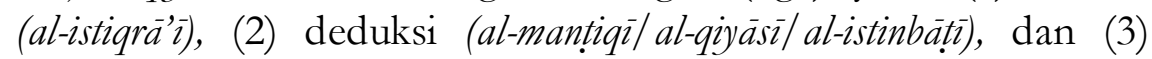
penyimpulan kausal (al-tamthili). ${ }^{21}$

${ }^{19}$ Ess Josef Van, "The Logical Structure of Islamic Theology," in $A n$ Antology of Islamic Studies, ed. Issa J. Boullata (McGill: Institute of Islamic Studies McGill University, 1970), 40.

20Periode Helenestik adalah periode kedua dari sejarak kawasan yang berbahasa Yunani. Yaitu periode kekuasaan Makedonia yang sisa-sisa terakhirnya terhapuskan oleh aneksasi Romawi terhadap Mesir sesudah kematian Kleopatra. Pada periode ini dalam bidang filsafat menyaksikan kelahiran mazhab Epikurean dan Stoa, serta tampilnya Skeptisisme sebagai ajaran yang telah terumuskan secara definitive.

${ }^{21}$ Kemudian penyimpulan kausal ini memiliki 5 (lima) metode, yaitu: 1) Tariqat al-Ittifäq (Method of Agreement), yaitu: metode persesuaian atau persamaan. Yakni jika dua peristiwa atau lebih dari suatu gejala tertentu memilki satu faktor yang sama, maka faktor tersebut dapat dianggap sebagai sebab dari gejalal itu, 2) Tariqat al-Ikhtiläf (Method of Difference), yaitu: metode perbedaan. Yakni jika terdapat dua peristiwa, yang satu berkaitan dengan satu gejala tertentu dan yang lain tidak, sedangkan pada peristiwa yang satu terdapat sebuah unsur dan pada peristiwa yang lain tidak terdapat, maka unsur itulah yang merupakan sebab dari gejala tersebut, 3) Tariqat al-Jam'bayn al-Ittifäq wa al-Ikhtiläf (Joint Method of Agreement and Difference), yaitu metode gabungan persesuaian dan perbedaan. Yakni jika di dalam dua peristiwa atau lebih terjadi gejala tertentu yang mempunyai satu unsur yang sama, 
Kemiripan itu adalah antara lain: metode al-tard menyerupai țariqat al-ittifäq. Sedangkan metode al-'aks menyerupai tariqat alikhtiläf. Adapun metode al-dawrān (al-tard wa al-'aks) menyerupai tariqat al-jam' bayn al-ittifäq wa al-ikbtiläf dan metode al-sabr wa altaqsim dan tanqīh al-manāt menyerupai tariqat al-bawāqī. ${ }^{22}$

Walaupun banyak persamaan antara qiyàs ushul fiqh dengan qiyās logika Aristoteles, bukan berarti tidak ada perbedaan antara keduanya. Ada beberapa perbedaan antara keduanya dari beberapa aspek yang antara lain dari aspek fungsi, premis (muqaddimab), makna had (definisi/batasan) dan tujuan.

Perbedaan antara keduanya dari aspek fungsi adalah qiyās ushul fiqh berfungsi żan (dugaan) dan ibtimäl (kemungkinan), sedangkan qiyàs logika Aristoteles berfungsi yakin dan pasti. ${ }^{23}$ Namun sebagian ulama menolak pendapat yang menyatakan bahwa qiyās ushul fiqh berfungsi żan (dugaan) dan ibtimäl (kemungkinan), karena qiyās ushul fiqh ada yang berfungsi dugaan dan ada yang berfungsi yakin. ${ }^{24}$

Perbedaan antara keduanya dari aspek premis adalah qiyās logika Aristoteles berdiri atas dua premis (mayor dan minor) dengan bantuan al-Hads (intuitif) dalam mengetahui keduanya. Sedangkan qiyās ushul fiqh berdiri atas satu premis dengan

sedangkan di dalam dua atau lebih tidak terjadi gejala tertentu dan tidak mempunyai persamaan kecuali tidak adanya unsur itu, maka unsur yang yang semata-mata membuat dua peristiwa itu berbeda merupakan akibat atau sebab dari gejala tersebut, 4) TTariqat al-Bawäqi (Method of Residues), yaitu metode sisa. Yakni terdapat beberapa gejala sebab akibat dari beberpa faktor dan dengan pengurangan faktor dapat mengurangi gejala tersbut, maka sisa dari gejala itu merupakan akibat dari sebab-sebab selebihnya, dan 5) Tariqat al-Taghayyur al-Nisbi (Method of Concomitant Variations), yaitu metode perubahan seiring. Yakni di antara dua peristiwa akan berubah jika adanya perubahan unsur peristiwa kedua dan sebaliknya unsur peristiwa kedua tidak mengalami perubahan jika unsur pada peristiwa pertama tidak berubah, maka dua unsur dalam dua peristiwa tersebut berhubungan sebagai sebab akibat. Baca: al-Sanūsī Aḥmad al-Tayyib, al-Istiqrā wa Atharuh fi al-Qawāáid alUsüliyyah wa al-Fiqbiyyab: Dirāsab Nażariyyah Tatbiqiyyah (Riyad-KSA: Dār alTadmuriyyah, 2008), 90-3.

22Ibid., 95.

${ }^{23}$ Alī Abd al-Fattāh al-Magribī, Diräsät 'Aqliyyah wa Rübìyyah fí al-Falsafah al-Islamiyyah (Cairo: Maktabah Wahbah 1995), 70.

24al-Tayyib, al-Istiqrä wa Atharuh, 101. 
bantuan nas (wahyu) dalam mengetauhi satu premis tersebut, karena memang qiyās ushul fiqh tidak hanya menggunakan dalil akal, tapi juga dalil 'aqli (sam'iyyah atau wahyu). Dari aspek makna had juga terdapat perbedaan antara keduanya. Makna had dalam logika Aristoteles adalah "sebuah kulliyät (generalitas) yang bisa sampai kepadanya dengan cara induktif', maka had adalah mu'arrif (pengenal) terhadap sebuah esensi zat. Sedangkan had dalam pandangan ulama ushul fiqh adalah sebagai pembeda antara mabdīd (suatu zat yang telah dibatasi) dengan zat lain. ${ }^{25}$

Sedangkan dari aspek tujuan, qiyās logika Aristoteles hanya bertujuan menemukan burhān atau bukti atas sesuatu yang sudah diketahui sebelumnya dan tidak bertujuan menemukan sesuatu hakikat yang baru. Adapun qiyās ushul fiqh bertujuan untuk menemukan sesuatu hakikat yang baru, yaitu berupa hukum baru $^{26}$ (hukum far').

Walau ada persamaan dan perbedaan antara antara qiyās ushul fiqh atau yang serting disebut ulama dengan qiyās (saja) dengan qiyās logika Aristoteles atau yang sering disebut dengan logika Aristoteles, tetap saja keduanya pada hakikatnya adalah suatu model nalar (cara berpikir) deduktif, karena pada dasarnya qiyās merupakan salah satu bentuk cara berpikir logis yang dinyatakan secara verbal. Kemudian digunakan sebagai cara kerja dalam memecahkan masalah hukum, sebagaimana tercermin dalam rukunnya, yaitu: al-asl, al-far', al-illah, dan bukm al-asl. Prosedur kerja ini disusun secara deduktif. Pernyataan pertama adalah al-așl, sebagai wadah hukum yang ditetapkan melalui nas. Pernyataan kedua adalah al-far', sebagai perkara yang akan ditentukan kedudukan hukumnya. Pernyataan ketiga adalah al'illah, sebagai alasan untuk menentukan kedudukan hukum al-far'. Pernyataan keempat adalah bukm al-asl, sebagai hukum "baru" yang ditetapkan terhadap al-far'.

Hal itu menunjukkan diberlakukannya oleh para ulama cara berpikir deduktif dalam menemukan hukum (istinbāt al-hukm) tentang sesuatu keadaan atau perbuatan mukallaf. Pernyataan yang terdapat dalam al-illah merupakan unsur yang menyamakan (common denominator) antara al-așl dengan al-far', sehingga dapat

25al-Magribī, Dirāsät 'Aqliyyah, 70.

26Ibid., 71. 
ditentukan bukm al-far'. Ciri yang melekat dalam cara kerja qiyās dan logika Aristoteles pada umumnya (verbal maupun simbolis), ialah mencari "titik temu".

Qiyās memang digolongkan oleh sebagian besar ulama sebagai salah satu dari empat dalil hukum yang telah disepakati di kalangan mazhab Sunni, namun dalil hukum berupa ayat alQur'an, teks hadis, dan ijma' adalah hakikatnya berisi material (dalil) hukum, atau dalil hukum sub-stantif, yang pada umumnya berisi perkataan (qawl Allah, qawl Rasül, dan qawl 'ulamā). Sementara itu, qiyās hakikatnya berisi prosedur kerja untuk menemukan dan menetapkan hukum yang dirujuk dari al-Qur'an (ayat) dan al-Sunnah (teks Hadis) atau dari teks kaidah usüliyyah atau kaidah fiqhiyyah.

Oleh karena itu, qiyās menempati kedudukan sebagai rujukan atau dalil metodologis, sebagaimana metode analogis untuk menafsirkan teks hukum (rechtsanalogische interpretatie) dalam sistem hukum Eropa Barat, yang dalam berbagai hal dianut dalam sistem hukum (nasional) Indonesia. Ini adalah upaya nalar deduktif dari sebuah teks dalam undang-undang (UU) positif sebuah negara terhadap sebuah persoalan hukum dengan cara menafsirkan sebuah teks UU positif untuk kemudian mengaplikasikannya secara deduktif dalam sebuah kasus hukum. ${ }^{27}$ Qiyās menggunakan dasar-dasar logika deduktif, yang secara umum tercermin dalam paradigma ushul fiqh. "Garis" yang menghubungkan dua "titik" -dua konsep dasar dalam matematika (logika deduktif simbolis)- antara ("titik") sistem hukum Islam dengan ("titik") sistem hukum Barat dapat dihubungkan (oleh "garis"), sebagaimana dapat disimpulkan dari pandangan beberapa pakar, seperti Mahdī Fadl Allah"28, 'Alī Abd al-Fattāh al-Maghribi'i', Abd al-Karīm al-As'adº, 'Ali Sāmī al-

${ }^{27}$ Artinya, sebuah ketetapan hukum bisa diambil dan ditetapkan (istinbāt al-bukm) dengan cara nalar deduktif (qiyas) melalui teks-teks al-Qur'an, alSunnah, Ijma' Ulama (yurisprodensi dari pendapat ulama atau hakim sebelumnya), al-Qawāid al-Usüliyyah, al-Qawäid al-Fiqhiyyah dan al-Qawānin alWad'iyyah (Undang-Undang Positif).

28Dalam bukunya, Mahdī Fadl Allah, al-Ijtihād wa al-Mantiq al-Fiqhi fi alIslàm (Baerut: Dār al-Tālíah, 1987).

29Dalam bukunya: al-Magribī, Dirāsät 'Aqlìyah, 
Nashār ${ }^{31}$ dan lain-lain yang menyatakan bahwa ilmu mantik shar ${ }^{6} i$ (qiyās) dalam ushul fiqh identik dengan ilmu logika atau paling tidak ia telah mengadaptasi dari ilmu logika Aristoteles.

Peran ushul fiqh dalam penetapan hukum-hukum fiqh tidak terlepas dari ketokohan Imam Shāfi'̄, peletak dasar dasar ilmu ini. Kemiripan ushul fiqh dengan logika dapat dibaca dari statemen Fakhruddin al-Rāzī yang menyamakan Shāfi'ì dengan Aristoteles. Jasa besar Shāfi'i sebenarnya terletak pada keberhasilannya mentransfomasikan ushul fiqh menjadi sebuah disiplin ilmu. Ada pula yang menyamakannya dengan Descartes. Kalau Descartes meletakkan dasar epistemologi pemikiran Barat, Shāfi'ì meletakkan pondasi pemikiran Islam.

\section{Catatan Akhir}

Dari uraian di atas dapat disimpulkan bahwa kuatnya peran dan pengaruh ilmu filsafat dan logika dalam metode istinbāt hukum Islam dalam ilmu ushul fiqh adalah karena sangat erat dan mendasarnya hubungan antara ushul fiqh dengan ilmu filsafat dan logika, yakni sebuah hubungan metodologis. Hal itu dikarenakan dalam ushul figh ada penggunaan dalil 'aqli (akal) disamping dalil 'aqlì (Qur'an dan Sunnah) sebagai dua sumber hukum Islam yang global. Sedangkan memfungsikan akal (nalar) untuk menganalisis sesuatu atau upaya mencari alasannya dikenal dua metode umum (global) dalam ilmu logika (mantiq), yaitu deduktif dan induktif. Logika adalah ilmu yang mempelajari cara memberi alasan, karena cara memberi alasan adalah dengan berpikir tentang berpikir. Secara lebih luas logik adalah studi tentang operasional memberi alasan, dengan mengamati faktafakta, mengumpukan bukti-bukti dan mengambil kesimpulan yang wajar, maka cara menarik kesimpulan dengan berpikir secara valid dinamakan berpikir logis.

Cara di sini adalah maksudnya metode. Beberapa cara nalar adalah beberapa metode nalar yang dengannya bisa dicapai apa yang dituju. Metode-metode ini semuanya dipinjam dari logika.

30Dalam bukunya: Abd al -Karīm al-As'ad, Bayn al-Nahw wa al-Mantiq wa Ulüm al-Sharìah (Riyad-KSA: Dār al-'Ulūm, 1983).

31Dalam bukunya: 'Ali Sāmī al-Nashār, Manāhij al-Babt Ind Mufakekirì alIslām (Bairut: Dār al-Nahdah al-'Arabiyyah, 1984). 
Jika pengetahuan merupakan konsepsi atau konfirmasi, maka demikian juga sesuatu yang diketahui. Jika merupakan konsepsi berarti ia adalah mu'arrif (pengenal) dan jika merupakan konfirmasi berarti ia adalah dalil, baik bersifat dugaan (;்nni)

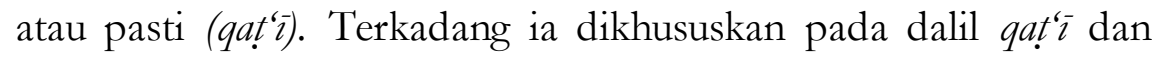
dalam keadaan demikian dalil żanni disebut indikasi. Bisa juga khusus pada sesuatu yang berasal dari akibat ke sebab, sedangkan sebaliknya disebut ta'lil, yakni perpindahan dari sebab ke akibat. Adalah jelas bahwa konfirmasi dari ulama-ulama terdahulu bukanlah hukum, tetapi semata-mata dalil terhadap konsepsi, yakni sesuatu yang merealisasikan konsepsi. Jika menurut keyakinan, dalil bisa berupa dugaan atau pasti, maka menurut petunjuk ia bisa berupa pembuktian petunjuk atau pembuktian sebab. Dalam konsepsi para ulama dahulu tentang cara-cara nalar terlihat jelas dominasi teori logika dan teori ilmu, terlebih ketika diterimanya pembagian dalam logika menjadi "konsepsi" dan "konfirmasi", bahwa konsepsi diperoleh melalui batasan, sedangkan konfirmasi melalui pembuktian. ${ }^{32}$

\section{Daftar Pustaka}

al-As'ad, Abd al -Karīm. Bayn al-Nabw wa al-Mantiq wa 'Ulūm alShari’ah. Riyad-KSA: Dār al-'Ulūm, 1983.

al-Magribī, Alī Abd al-Fattāh. Dirāsāt 'Aqliyyah wa Rühiyyah fì alFalsafah al-Islämiyyah. Cairo: Maktabah Wahbah 1995.

al-Nashār, 'Ali Sāmī. Manāhij al-Baht Ind Mufakekirì al-Islām.

Bairut: Dār al-Nahdah al-'Arabiyyah, 1984.

al-Tayyib, al-Sanūsī Aḥmad. al-Istiqrā wa Atharuh fì al-Qawāid al-

Ușüliyyah wa al-Fiqhiyyah: Dirāsah Nażariyyah Tatbiqiyyah.

Riyad-KSA: Dār al-Tadmuriyyah, 2008.

al-Zuhaylī, Wahbah. Usūul al-Figh al-Islämi. Vol. 1. DamascusSuriah: Dār al-Fikr, 1996.

Arfan, Abbas. Geneologi Pluralitas Mą̧hab dalam Hukum Islam.

Malang: UIN Malang Press, 2008.

Fadl Allah, Mahdī. al-Ijtihād wa al-Mantiq al-Fiqhi fi al-Isläm.

Baerut: Dār al-Tāli‘ah, 1987.

${ }^{32}$ Hasan Hanafi, Dari Akidah ke Revolusi: Sikap Kita Terhadap Tradisi Lama, trans. Asep Usman Ismail (Jakarta: Paramadina, 2003), 172. 
Hallaq, Wael B. Sejarah Teori Hukum Islam. Jakarta: Rajawali Pres, 2000.

Hanafi, Hasan. Dari Akidah ke Revolusi: Sikap Kita Terhadap Tradisi Lama. Translated by Asep Usman Ismail. Jakarta: Paramadina, 2003.

Ismā̄î̀l, Sha'bān Muhammad. Dirāāât Hawl al-Ijmā' wa al-Qiyās. Cairo-Mesir: Maktabah al-Nahdah al-Mișriyyah, t.th.

Kamal, Zainun. Ibn Taimiyah Versus Para Filosof: Polemik Logika. Jakarta: Rajawali Pers, 2006.

Mu'allim, Amir and Yusdani. Konfigurasi Pemikiran Hukum Islam. Translated by Konfigurasi Pemikiran. Yogyakarta: UII Press, 2001.

Raper, Jan Hendrik. Pengantar Filsafat. Yoyakarta: Kanisius, 1996. Umar, Muhammad Hasbi. Nalar Figh Kontemporer. Jakarta: GP Press, 2007.

Van, Ess Josef. "The Logical Structure of Islamic Theology." In An Antology of Islamic Studies, edited by Issa J. Boullata. McGill: Institute of Islamic Studies McGill University, 1970. Zahrah, Abū. Ușūl al-Fiqh. Mesir: Dār al-Fikr al-'Arabī, 1990. 